\title{
Alkaline Phosphatases from Mycobacterium smegmatis
}

\author{
By HUGO L. DAVID \\ Service de la Tuberculose et des Mycobactéries, \\ Institut Pasteur, Paris 15, France
}

(Received 2 I January 1977; revised 28 March 1977)

Mycobacterium smegmatis formed an alkaline phosphomonoesterase (EC 3.I.3.I) and an alkaline phosphodiesterase (EC 3.I.4.I). The former was regulated by inorganic phosphate and was repressed in medium containing a high concentration of phosphate. The synthesis and the function of the alkaline phosphodiesterase were not controlled by inorganic phosphate.

\section{INTRODUCTION}

The alkaline phosphatases are regulated differently in different micro-organisms. In some, the alkaline phosphomonoesterase is synthesized only when the concentration of orthophosphate in the medium is limiting (Bhatti, 1974; Garen \& Echols, 1962; Horiuchi, Horiuchi \& Mizuno, 1959; Stewart \& Stewart, 197I; Taniguchi \& Tsugita, 1966; Torriani, 1960). In Staphylococcus aureus and in Bacteroides ruminicola, the enzyme is constitutive (Cheng \& Costerton, 1973; Kuo \& Blumenthal, 1961). Bacillus subtilis also forms a phosphodiesterase that, like its phosphomonoesterase, is repressible by orthophosphate (Taniguchi \& Tsugita, 1966; Takeda \& Tsugita, 1966). These enzymes have not been reported before in the mycobacteria. In view of their possible taxonomic importance, it was of interest to establish their occurrence, and to examine their regulation in such bacteria.

\section{METHODS}

Bacteria and growth conditions. Mycobacterium smegmatis HB4495 was from the culture collection of the Institut Pasteur, Paris, and was kindly supplied by Henry Boisvert. Bacteria were grown in a modified Proskauer \& Beck medium containing $\left(\mathrm{g}^{-1}\right)$ : ferric ammonium citrate, 0.05 ; citric acid, $2 \cdot 0$; glycerol, $2 \cdot 0$; potassium sulphate, 0.6 ; dipotassium phosphate, 4.0 ; sodium glutamate, I.75; magnesium chloride, I $\cdot 2$; and Tween 80 , final concentration $0.05 \%(\mathrm{w} / \mathrm{v})$. The $\mathrm{pH}$ was adjusted to 6.8 to 7.0 before autoclaving. When required, the medium was prepared without phosphate and phosphate was added to the desired final concentration. Cultures were incubated in a New Brunswick R86 water-bath reciprocal shaker at 75 rev. $\min ^{-1}$ and at $37^{\circ} \mathrm{C}$.

Growth was estimated by monitoring the extinction of cultures at $650 \mathrm{~nm}$ using a Coleman Jr model A20 spectrophotometer (Coleman Instruments, New Jersey, U.S.A.). In the exponential phase of growth, $\mathrm{I} \cdot 0 \mathrm{mg}$ dry wt bacteria $\mathrm{ml}^{-1}$ was equivalent to an extinction of 0.62 at $650 \mathrm{~nm}$. When growth was allowed to continue beyond the exponential phase, clumping occurred and so the mass was estimated by weighing bacterial suspensions washed in distilled water and dried in an oven at $80^{\circ} \mathrm{C}$ to constant weight.

Assay of alkaline phosphatase. The alkaline phosphatases were usually assayed in reaction mixtures containing washed bacteria (or enzyme protein) in $1.0 \mathrm{ml} 0.05 \mathrm{M}-\mathrm{Tris} / \mathrm{HCl}$ buffer, $\mathrm{pH} 8 \cdot 0$, containing $\mathrm{I} \mathrm{mm}$ $\mathrm{MgSO}_{4}$, plus $\mathrm{I} \cdot 0 \mathrm{ml} 20 \mathrm{~mm}$ - -nitrophenyl phosphate (NPP) or Io mM-bis-p-nitrophenyl phosphate (bis$\mathrm{NPP}$ ) (both from Sigma). The reaction mixtures were incubated at $37^{\circ} \mathrm{C}$ for the desired time, and $\mathrm{I} \cdot \mathrm{O} \mathrm{ml}$ $\mathrm{I} \cdot \mathrm{O} \mathrm{M}-\mathrm{Na}_{2} \mathrm{CO}_{3}$ was then added. The amount of nitrophenol liberated was estimated spectrophotometrically at $4 \mathrm{IO} \mathrm{nm}$ using an appropriate calibration curve. Enzyme activities are expressed as pmol nitrophenol liberated per mg dry wt bacteria per hour.

Phosphorus estimations. Inorganic phosphorus $\left(\mathrm{P}_{\mathrm{i}}\right)$ was assayed by the Fiske \& Subbarow method (Dryer, Tammes \& Routh, 1957). 


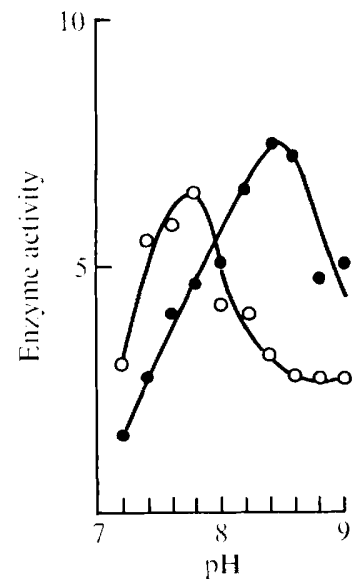

Fig. I

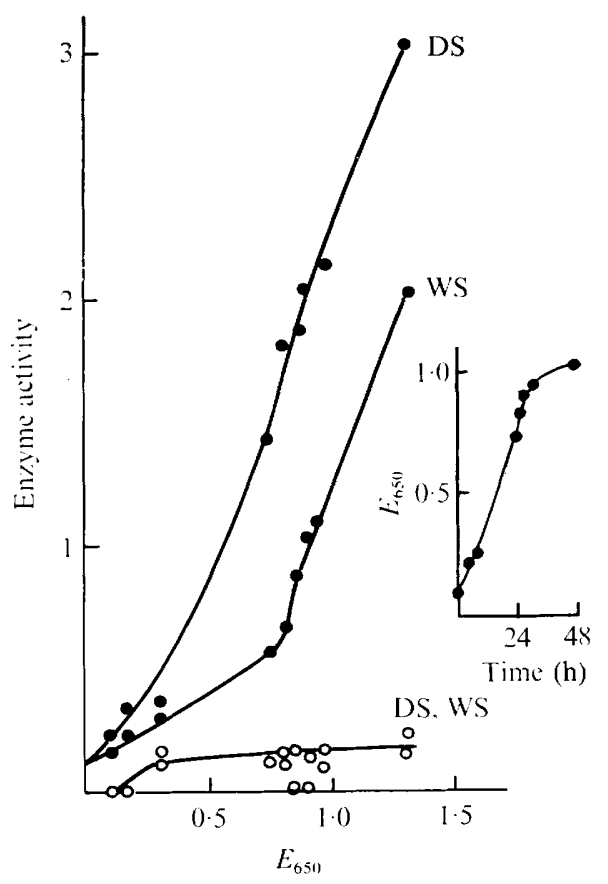

Fig. 2

Fig. I. Effect of pH on alkaline phosphomonoesterase $(O)$ and phosphodiesterase $(O)$. Buffers of the indicated $\mathrm{pH}$ were prepared by mixing Tris and Tris hydrochloride. Enzyme activities are expressed as pmol nitrophenol liberated (mg dry wt) $)^{-1} \mathrm{~h}^{-1}$.

Fig. 2. Differential rate of synthesis of alkaline phosphomonoesterase $(O)$ and phosphodiesterase (O). A culture was grown to an extinction at $650 \mathrm{~nm}$ of $0 \cdot \mathrm{I}$, and then samples were taken at intervals for $48 \mathrm{~h}$. Each sample was filtered through a $0.8 \mu \mathrm{m}$ pore-size Millipore filter, and the enzyme activities were measured in the bacteria trapped in the filters (WS) and in the filtrate (DS). The initial and final concentrations of $P_{i}$ in the medium were 25.7 and $20.0 \mathrm{~mm}$ respectively. Inset: growth curve of $M$. smegmatis. Enzyme activities are expressed as pmol nitrophenol liberated (mg dry wt) ${ }^{-1}$ $\mathrm{h}^{-1}$.

Preparation of extracts. Washed bacteria were added to about twice their volume of washed sand and then frozen. The frozen material was finely broken and then manually ground in a mortar in an ice bath until completely melted. Tris/ $\mathrm{HCl}$ buffer, $\mathrm{pH} 8 \cdot 0$, containing I mM- $\mathrm{MgSO}_{4}$ was added and the mixture was centrifuged at $5000 \mathrm{~g}$ for $20 \mathrm{~min}$. The supernatant was filtered through a $0.8 \mu \mathrm{m}$ pore-size Millipore filter, and the crude enzyme preparation was precipitated with $\left(\mathrm{NH}_{4}\right)_{2} \mathrm{SO}_{4}$ at o to $40 \%$ saturation (fraction I) and 40 to $80 \%$ saturation (fraction II).

\section{RESULTS}

\section{Preliminary observations}

Bacteria harvested during the stationary phase of growth (2- to 3-week-old cultures) hydrolysed NPP and bis-NPP without a lag. These observations suggested that $M$. smegmatis formed a phosphomonoesterase (mono-AP) and a phosphodiesterase (di-AP). Most of the mono-AP in cell-free extracts was precipitated by ammonium sulphate at o to $40 \%$ saturation and most of the di-AP was precipitated at 40 to $80 \%$ saturation, indicating that the hydrolysis of NPP and bis-NPP was caused by different enzymes.

\section{Properties of the enzymes}

The optimum $\mathrm{pH}$ for mono-AP was about $7 \cdot 8$ and for di-AP was about $8 \cdot 4$ (Fig. I). The amount of nitrophenol released was proportional to the concentration of NPP up to about $5 \mathrm{~mm}$, and to the concentration of bis-NPP up to about $7.5 \mathrm{~mm}$, as well as to the cell concentration in the reaction mixtures. 
Table I. Utilization of $P_{i}$ by $M$. smegmatis

\begin{tabular}{|c|c|c|c|}
\hline \multicolumn{2}{|c|}{$P_{1}$ concn $(\mathrm{mM})$} & \multirow{2}{*}{$\begin{array}{l}\text { Bacterial dry wt } \\
\left(\mathrm{mg} \mathrm{ml}^{-1}\right)\end{array}$} & \multirow{2}{*}{$\begin{array}{c}\mathbf{P}_{1} \text { utilized } \\
\left(\mu \mathrm{mol} \mathrm{mg}^{-1}\right)\end{array}$} \\
\hline Initial & Final* & & \\
\hline 200 & $46 \cdot 7$ & $5 \cdot 2$ & $29 \cdot 48$ \\
\hline 160 & $440^{\circ}$ & $4 \cdot 5$ & $25 \cdot 78$ \\
\hline 120 & $42 \cdot 0$ & $3 \cdot 8$ & $20 \cdot 53$ \\
\hline 80 & $3 I \cdot 0$ & $3 \cdot 4$ & 14.41 \\
\hline 40 & $24 \cdot 3$ & $2 \cdot 7$ & $5 \cdot 8 \mathrm{I}$ \\
\hline 20 & I I $\cdot 7$ & $\mathrm{I} \cdot 6$ & $5 \cdot 19$ \\
\hline
\end{tabular}

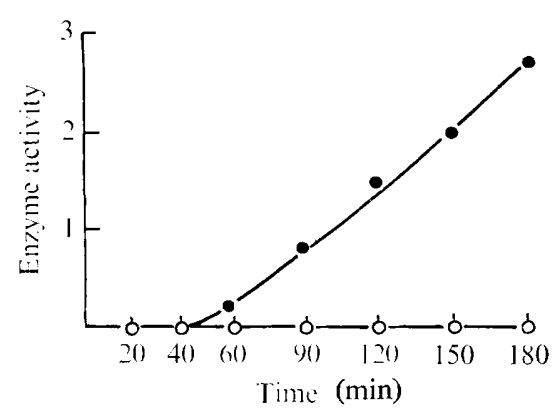

Fig. 3. Effect of $\mathrm{P}_{\mathrm{i}}$ on the synthesis and expression of alkaline phosphomonoesterase. Bacteria grown in high- $P_{i}$ medium were harvested by centrifugation, washed, divided into two portions and added to $(\bigcirc) \mathrm{P}_{\mathrm{i}}$-free medium or $(\bigcirc)$ high- $\mathrm{P}_{\mathrm{i}}(20 \mathrm{~mm})$ medium. Samples were taken at the indicated intervals, the bacteria were washed and the enzyme activity was measured in the presence of $100 \mu \mathrm{g}$ streptomycin $\mathrm{ml}^{-1}$. Enzyme activities are expressed as pmol nitrophenol liberated (mg dry wt) ${ }^{-1} \mathrm{~h}^{-1}$.

The $K_{\mathrm{m}}$ values of the partially purified enzymes were about $0.7 \mathrm{~mm}$ and $0.0 \mathrm{Im}$ for NPP and bis-NPP, respectively. Mono-AP was inhibited by $\mathrm{P}_{\mathrm{i}}\left(K_{\mathrm{i}}=0.3 \mathrm{mM}\right)$, but di-AP was not sensitive to $P_{i}$ at the concentration used in these experiments (ro mM). However, di-AP was about $30 \%$ inhibited by $100 \mathrm{~mm}-\mathrm{P}_{\mathrm{i}}$. The ratio $K_{\mathrm{i}} / K_{\mathrm{m}}$ was 0.43 for mono-AP and 0.92 for di-AP.

\section{Effect of $P_{i}$ on growth and enzyme synthesis}

To study the effect of $\mathrm{P}_{\mathrm{i}}$ on growth and on synthesis of the phosphatases, bacteria were inoculated into media containing between $I$ and $200 \mathrm{mM}-\mathrm{P}_{\mathrm{i}}$. The cultures were incubated for Io days at $37^{\circ} \mathrm{C}$, and the amount of growth, the final concentration of $P_{1}$ and the enzyme activities were then estimated. There was no growth at $P_{i}$ concentrations below $5 \mathrm{mM}$ and $P_{i}$ was in excess at above about $40 \mathrm{~mm}$. At the end of the experiment (Io days incubation) unused $P_{i}$ remained in the medium (Table $I$ ). The activity of mono-AP was highest in the medium containing the lowest final concentration of $\mathrm{P}_{\mathrm{i}}$, whereas the di-AP activity was independent of the $P_{i}$ concentration. When the enzyme activities were measured in bacteria harvested at different stages of the growth curve, mono-AP was virtually absent at all times (Fig. 2). The increase in the differential rate of synthesis of di-AP at cell densities above $\mathrm{I} \cdot \mathrm{O}$ was possibly due to increased permeability, and some cell lysis that usually occurs when bacterial cultures reach the stationary phase of growth.

\section{Regulation of mono- $A P$}

The above observations clearly indicated that di-AP was synthesized constitutively and that its activity was not inhibited by $\mathrm{P}_{\mathrm{i}}$. On the other hand mono-AP was inhibited by $\mathrm{P}_{j}$, and since no activity was detected in washed bacteria grown in high- $\mathrm{P}_{\mathbf{i}}$ medium it was possible that the synthesis of the enzyme was repressed. To examine the regulation of mono-AP, 
bacteria grown in high- $P_{i}$ medium were washed and divided between two vials containing $P_{i}$-free medium and high- $P_{i}$ medium respectively. The vials were incubated in a reciprocal shaker and at intervals (see Fig. 3) samples were withdrawn and mono-AP activity was measured. Mono-AP activity began to be expressed about $50 \mathrm{~min}$ after the bacteria had been transferred to $P_{i}$-free medium (Fig. 3). This was not caused by the removal of $P_{i}$ when the harvested bacteria were washed to perform the assay since bacteria in the second vial (containing high- $P_{i}$ medium) showed no activity.

\section{DISCUSSION}

Mycobacterium smegmatis synthesized two non-specific alkaline phosphatases. Evidence that the hydrolysis of NPP and bis-NPP was caused by distinct enzymes was provided by the observations that the activities exhibited distinct optimum $\mathrm{pH}$ values, had distinct $K_{\mathrm{m}}$ values, were affected differently by $\mathrm{P}_{\mathrm{i}}$, were regulated differently, and could be partially separated by ammonium sulphate precipitation.

Alkaline phosphomonoesterase (optimum pH about 7.8) was not found in the bacteria grown in high $\mathrm{P}_{\mathrm{i}}$-medium (initial concentration 20 to $25 \mathrm{~mm}$ ), but was fully expressed in bacteria allowed to reach the stationary growth phase (grown for 2 to 3 weeks). The enzyme activity was dependent on the concentration of $P_{i}$ in the medium at the time when the bacteria were harvested. When the bacteria were grown in high- $P_{i}$ medium, washed to remove $\mathrm{P}_{\mathrm{i}}$ and resuspended in $\mathrm{P}_{\mathrm{i}}$-free medium, synthesis of mono-AP began after a lag of about $50 \mathrm{~min}$. Thus, as in E. coli (Garen \& Garen, 1963; Torriani, I960) and other microorganisms, the mono-AP from $M$. smegmatis was regulated by the concentration of $\mathrm{P}_{\mathrm{i}}$ in the medium.

Throughout this investigation, di-AP activity was detected irrespective of the presence of $\mathrm{P}_{\mathrm{i}}$ in the growth medium. We, therefore, concluded that di-AP (optimum $\mathrm{pH}$ about $8 \cdot 4$ ) was consitutive and was not controlled by orthophosphate.

\section{REFERENCES}

Bhatti, A. R. (1974). Alkaline phosphatase of Serratia marcescens. Archives of Microbiology 95, $255^{-256 .}$

Cheng, H. J. \& Costerton, J. W. (1973). Localization of alkaline phosphatase in three gram-negative rumen bacteria. Journal of Bacteriology $\mathbf{1 1 6}$, 424-440.

Dryer, R. L., TAmmes, A. R. \& Routh, G. J. (I957). The determination of phosphorus and phosphatase with $N$-phenyl-p-phenylenediamine. Journal of Biological Chemistry 225, I77-183.

Garen, A. \& Echols, H. (1962). Genetic control of induction of alkaline phosphatase synthesis in Escherichia coli. Proceedings of the National Academy of Sciences of the United States of America 48, 1398-1402.

GAREN, A. \& GAREN, S. (1963). Genetic evidence on the nature of the repressor for alkaline phosphatase in Escherichia coli. Journal of Molecular Biology 6, 433-438.

Horiuchi, T., Horiuchi, S. \& Mizuno, D. (I959). A possible negative feedback phenomenon con- trolling formation of alkaline phosphomonoesterase in Escherichia coli. Nature, London 183 , 1529-1530.

Kuo, M. H. \& Blumenthal, H. J. (I96I). Absence of phosphatase repression by inorganic phosphate in some microoganisms. Nature, London r9o, 29-3I.

Stewart, D. B. \& Stewart D. J. (I97I). Esterases and phosphatases of Escherichia coli serotypes isolated from the pig. Journal of General Microbiology 65, I75-I 84 .

Taniguchi, H. \& Tsugita, A. (I966). Phosphoesterases of Bacillus subtilis. I. Purification and properties of phosphodiesterases. Journal of Biochemistry 60, 372-380.

TAkeda, H. \& Tsugita, A. (I966). Phosphoesterases of Bacillus subtilis. II. Crystallization and properties of alkaline phosphatase. Journal of Biochemistry 6r, 23I-I42.

TORRIANI, A. (I960). Influence of organic phosphate in the formation of phosphatases by Escherichia coli. Biochimica et biophysica acta 38, 460-479. 